\title{
The PhD Supervisory Relationship Gap in the Accounting Discipline: A Study in a Malaysian Public University
}

\author{
Erlane K Ghani (Corresponding author) \\ Universiti Teknologi MARA \\ Malaysia \\ E-mail: erlanekg@salam.uitm.edu.my \\ Jamaliah Said \\ Universiti Teknologi MARA \\ Malaysia
}

Received: September 12, 2013 Accepted: October 7, 2013 Published: November 29, 2013

doi:10.5296/ire.v2i1.4639 URL: http://dx.doi.org/10.5296/ire.v2i1.4639

\begin{abstract}
This study examines the nature and quality of supervisory relationship of the $\mathrm{PhD}$ supervisors and $\mathrm{PhD}$ supervisees based on questionnaire survey on $100 \mathrm{PhD}$ supervisors and $\mathrm{PhD}$ supervisees. The results show that $\mathrm{PhD}$ supervisee group tend to agree that having common research interest and professional reputation of the supervisors as an important factor whereas the $\mathrm{PhD}$ supervisors perceived the $\mathrm{PhD}$ supervisees' past research and work experience as a major influence in choosing their supervisee. The results also show that there is a significant different in supervisory selection criteria between $\mathrm{PhD}$ supervisors and supervisees in terms of common research interest and $\mathrm{PhD}$ supervisee's/supervisor's work habit and personality. A key finding in this study is that the selection criteria of supervisory relationship characteristics vary between the $\mathrm{PhD}$ supervisors and supervisees. Therefore, it is recommended that $\mathrm{PhD}$ supervisees need to be aware of the supervisory selection criteria of their potential supervisors in order to be accepted by the later party. $\mathrm{PhD}$ supervisees also need to be aware of the supervisory relationship characteristics expected by their $\mathrm{PhD}$ supervisors need order to complete their study successfully.
\end{abstract}


Keywords: $\mathrm{PhD}$, supervisee, supervisor, supervisory relationship, selection criteria

\section{Introduction}

The government, particularly in Malaysia, and the educational institutions of higher learning are striving to attract more students to embark on research supervision. Research supervision in education refers to a process of fostering and enhancing learning, research and communication at a higher level (Laske \& Zuber-Skerritt, 1996). It is considered the highest and advanced level of teaching in the education system (Connell, 1985). Research supervision is intensive and interpersonally and often regarded as a critical factor to the success of graduate supervisees (Freeman, 1992; Dye, 1994; Dinham \& Scott, 1999; Johnston, 1999). Dinham and Scott (1999) noted that "The student-supervisor relationship has the potential to be wonderfully enriching and productive, but it can also be extremely difficult and personally devastating".

In general, research supervision often involves two parties: the supervisors and the supervisees. These parties often have different perception on research supervision (Johnston, 1999). The supervisees often perceived an ideal supervision is a supervision that could assist them in their study where they learn about research and how to conduct research apart from achieving their personal and professional goals. Supervisors on the other hand often perceived that their supervision could provide guidance and create research situations. In addition, supervisors could conduct research projects with supervisees to enhance their learning, research as well as reputation (Laske \& Zuber-Skerritt, 1996).

In most cases, supervisor is given the role to lead the supervisee in his/ her study process (Bernard and Goodyear, 1992). Throughout this process, a supervisor is expected to facilitate the supervisee and assist the supervisees. However, where an episode requires long process such as $\mathrm{PhD}$ journey, conflict may arise and magnitude of relationship may change over time which of consequence, could affect the supervisory relationship. Motivated by this argument, this study aims to examine the quality and nature of supervisory relationship between $\mathrm{PhD}$ supervisors and supervisees.

The remainder of this paper is structured as follows. The next section provides a review of relevant literature. Section 3 provides the research questions underpinning this study and section 4 outlines the research design. The results are presented in section 5. A summary and conclusion are provided in the last section.

\section{Literature Review}

Research on research supervision is becoming an eminent research interest for the past decades (Dye, 1994; Dinham \& Scott, 1999). Within this area, one important component that has been researched into is the supervisory relationship between the supervisors and supervisees. The supervisory relationship has become a critical component to achieve postgraduate qualification due to the recognition that it has become a central process for successful completion of postgraduate study (Freeman, 1992; Dye, 1994; Dinham \& Scott, 1999). It refers to two ways interact process between the supervisor and supervisee in continuingly engage each other within the spirit of open-mindedness, professionalism, respect 
and collegiality. It is seen as an interaction process that involves two parties with the same converging and diverging interests (Dye, 1994). The balance of these interests, therefore, is critical in ensuring success completion of postgraduate study.

The interest in researching supervisory relationship is due to factors that attributed to the postgraduate supervisees' success rate such as supervisee's dissatisfaction and low completion rates. Studies have shown that supervisee's satisfaction with their research study plays an important role to their study success (Hockey, 1991; Acker et al., 1994). They argued that it is important to get the relationship off to a good start and to maintain effective relations through the varying stresses and challenges of a research degree. Supervisees who have just started their study are sometimes unsure what expectations that their supervisors have (Cornwall et al., 1977; Ronnested \& Skovholt, 1992). Therefore, it is often important that the supervisor and supervisee are clear about the expectations they have of each other and comfortable about re-negotiating expectations during the research process.

The area of supervisory relationship has been researched into in the past decade and a number of studies have evidenced the importance of characteristics of supervisory relationship. The characteristics identified in the literature could impact the perception of the supervisors and supervisees and of consequence, create an expectation gap between the supervisor and the supervisee (Moses, 1984; Grant, 1999; Gurr, 2001; Armstrong, 2004; Pearson and Kayrooz, 2005). However, there is still a lack of understanding on this issue and how supervisees could strategise in order to maintain good supervisory relationship. Understanding how supervisory relationship is accepted and acted upon by supervisees is an area worthy of more serious research efforts, to extend our understanding of the research process. This study aims to further examine the perceived supervisory relationship among $\mathrm{PhD}$ supervisors and $\mathrm{PhD}$ supervisees.

\section{Research Questions}

This study has two objectives. They comprise:

(1) To determine the supervisory selection criteria of the $\mathrm{PhD}$ supervisors and $\mathrm{PhD}$ supervisees.

(2) To examine the perceived supervisory relationship between the $\mathrm{PhD}$ supervisors and supervisees.

The most important decision that $\mathrm{PhD}$ supervisees need to make before embarking for their research study is the selection of their PhD supervisors. Most PhD supervisees have the choice to choose who they want to be supervised with although there are $\mathrm{PhD}$ supervisees who were not given the privileged to do so. $\mathrm{PhD}$ supervisees who have the choice to choose their $\mathrm{PhD}$ supervisors often rely on a set of unplanned criteria (Ray, 2007) which resulted to regrets and lack of motivation which eventuate to poor quality of research output. Such arguments indicated that $\mathrm{PhD}$ supervisees need to set a strategy in selecting their potential $\mathrm{PhD}$ supervisors in an objective manner. 
Generally, PhD supervisees could determine the several qualities that they expect of their PhD supervisors. These qualities however may or may not be of equal significance to the $\mathrm{PhD}$ supervisees (Ray, 2007). Arguably, the selection criteria become the critical factors that would determine the matching degree between the $\mathrm{PhD}$ supervisees and $\mathrm{PhD}$ supervisors (Eggleston \& Delamont, 1983; Wright \& Lodwick, 1989). In ideal circumstance, the PhD supervisees should be able to determine the criteria and its importance that they would their $\mathrm{PhD}$ supervisors to have and consequently, select their $\mathrm{PhD}$ supervisors who fits best (Ray, 2007). In a situation where $\mathrm{PhD}$ supervisees who were not given the choice to choose their $\mathrm{PhD}$ supervisors, often the $\mathrm{PhD}$ supervisors were given the choice by the graduate school whether the potential $\mathrm{PhD}$ supervisees that they have been allocated to could be accepted. Therefore, the following research questions are developed:

RQ1: What are the supervisory relationship criteria of the $\mathrm{PhD}$ supervisors and supervisees?

The importance of the supervisory relationship often refers in two perspectives, namely the role of supervisor and the standard of supervision being delivered (Pearson \& Brew, 2002; McMorland et al., 2003). PhD supervisors are responsible to do the monitoring role in the research progress and to ensuring their supervisees would master appropriate research skills as well as completing their study. Where issues arise between the $\mathrm{PhD}$ supervisors and $\mathrm{PhD}$ supervisees, many universities provide opportunities for the supervisees to change their supervisors although they are encouraged to try and solve any issues occurring between the $\mathrm{PhD}$ supervisees and their supervisors. This is because the $\mathrm{PhD}$ supervisors may not be aware of the supervisees' concerns and once known, would be able to take appropriate corrective action.

Studies in the education supervisory literature have identified that often supervisees who did not complete their studies have different expectations of their supervisors (Graham \& Grant, 1997; Kam, 1997; Delamont et al., 2000, Smeby, 2000; Pearson \& Brew, 2002). These studies argued that the different in the expectations caused an expectation gap between the supervisees and the supervisors. Of consequence, the expectation gap may affect how supervisees progress in their research dissertations (Wisker \& Sutcliffe, 1999). Other studies, however, suggested that other factors such as supervisory intervention and power relationships between supervisors and supervisees could affect the outcome for supervisees in completing their research dissertations. This is consistent with Sharp and Howard where they identified several problems experienced by supervisees on the research journey in completing their dissertation (2000, pp. 164). They noted that:

\section{"'There are a number of ways in which research progress may be affected by what may be termed "personal" factors such as illness, loss of motivation, occurrence of other opportunities and the need to search for a job",}

The notation above indicates that there is an expectation gap on the perceive importance of factors related to supervisory relationship. Further, most studies were conducted on a different setting that did not specifically focused on $\mathrm{PhD}$. Of consequence, there is still a lack of understanding on this issue and how supervisees could strategise in order to maintain good 
supervisory relationship. This study aims to examine this issue by examining the following research questions:

RQ2: Are the $\mathrm{PhD}$ supervisors and supervisees satisfied with their supervisory relationship?

RQ3: What do the PhD supervisors and supervisees perceived the impact of supervisory characteristics on the degree outcome?

RQ4: What is the perceived impact of supervisory characteristics on supervisee's satisfaction and degree outcome of the $\mathrm{PhD}$ supervisors and supervisees?

\section{Research Design}

\subsection{Sample Selection}

The sample for this study is drawn from academics in the Faculty of Accountancy of a public university in Malaysia that were/ are currently $\mathrm{PhD}$ supervisors and $\mathrm{PhD}$ supervisees studying in local or overseas universities. The choice of this sample is considered appropriate because of the adequacy of obtaining a number of a match $\mathrm{PhD}$ supervisors and $\mathrm{PhD}$ supervisees. This sample is also chosen to enable the researchers to identify the respective $\mathrm{PhD}$ supervisors and their supervisees so their responses could be matched.

\subsection{Development of Data Instrument}

The questionnaire survey is adapted from the work of Drysdale (2001) with appropriate modifications to fit the purpose and context of this study. Two sets of questionnaire are developed. One set of questionnaire is developed for respondents who were/ are supervising $\mathrm{PhD}$ supervisees. The second set of questionnaire is developed for respondents who were/ are supervised by $\mathrm{PhD}$ supervisors.

\subsubsection{Questionnaire for $\mathrm{PhD}$ Supervisors}

For the first set of questionnaire which is intended to be given to $\mathrm{PhD}$ supervisors as respondents, there are three sections. Section A relates to demographic profiles. Demographic information on each respondent includes gender, age, position and supervising experience. The respondents are asked to complete these variables in categorical form.

In this questionnaire also, the respondents are asked whether they had a choice in supervising the intended supervisees. If their answer is yes, the respondents are asked on the importance of five factors in their decision to supervise their supervisees. The factors are common research interest, supervisees' past research and academic experience, supervisees' work habits and personality, recommendation from colleague and recruited by supervisee. The respondents are asked to complete this question on a 5-point scale of 1 being 'very unimportant' to 5 being 'very important'. Finally, in Section A, the respondents are asked on their satisfactory level in supervising the named $\mathrm{PhD}$ supervisee using a 5-point scale of 1 being 'very satisfied' to 5 being 'very dissatisfied'. 
Section B seeks respondents' responses concerning the supervisory characteristics and characteristics of supervision. This section has two parts. The first part involves examining the impact of identified characteristics on the $\mathrm{PhD}$ supervisors' relationship with their supervisees. There are 13 questions in this part which includes availability to the supervisee, promptness in returning messages to supervisee, expectation made known to supervisee at beginning of program, schedule to accommodate demands in supervising supervisee, availability to discuss academic issues with supervisee, support given to supervisee's academic problems, belief in supervisee's ability, guidance in preparation of proposal, guidance in writing thesis, amount of constructive feedback provided to supervisee's research proposal, amount of constructive feedback provided to supervisee's thesis, and open to ideas on the direction of supervisee's research. The respondents are asked to response using a 5-point scale of 1 being 'very negative impact' to 5 being 'very positive impact'.

The second part of Section B involves examining the impact of identified characteristics on the $\mathrm{PhD}$ supervisors with the supervisees' studies and degree outcome. This part consists of four questions which include knowledge on supervisee's research topic, supporting letters, regular meetings during proposal, generation or writing stages and scheduled meetings with supervisee to accomplish necessary tasks. The respondents are asked to response using a 5-point scale of 1 being 'very negative impact' to 5 being 'very positive impact'.

Section $\mathrm{C}$ relates to examining the satisfaction and impact of identified characteristics of supervisory relationship with the supervisee's study and degree outcome. There are two parts in this section. The first part focuses on the satisfaction on the characteristics in supervisory relationship. There are 11 questions in this part which include supervisee's accessibility, schedule in meeting demands of graduate school, ability to meet deadlines, enthusiasm in his/ her research, attitude towards their studies, competency in undertaking a research project, willingness to seek new information, willingness in sharing authorship on joint projects, motivation to complete their program on time and willingness to admit mistakes. The respondents are asked to complete this question on a 5-point scale of 1 being 'very dissatisfied' to 5 being 'very satisfied'.

The second part of Section $\mathrm{C}$ seeks to examine the impact of the characteristics identified on supervisees' study and degree outcome. There are 11 questions in this part. All the eleven questions are similar to the questions in the first part. However, the responses are on the impact of the characteristics of supervisory relationship towards the supervisees' study and degree outcome whereas in the first part of Section $\mathrm{C}$, the respondents are asked to response the eleven questions towards the supervisory relationship. The respondents are asked to response using a 5-point scale of 1 being 'very negative impact' to 5 being 'very positive impact'.

\subsubsection{Questionnaire for PhD Supervisees}

The second set of questionnaire is intended for $\mathrm{PhD}$ supervisees as respondents. There are three sections. Section A relates to demographic profiles. Demographic information on each respondent includes gender, age and years of completing program. The respondents are asked to complete these variables in categorical form. The respondents are also asked whether they 
have a choice in determining who would supervise them. If their response is yes, the respondents are asked to identify the importance of five factors, namely, common research interest, supervisor's professional reputation, supervisor's work habits and personality, recommendation from colleague and recruited by supervisor. The respondents are asked to complete this question on a 5-point scale of 1 being 'very unimportant' to 5 being 'very important'.

This section also asked the respondents whether they have changed their $\mathrm{PhD}$ supervisors during their program and if yes, their main reason. Among the reasons that the respondents could select are change in research interest, fail to meet supervisor's expectations, supervisor could not meet professional needs, supervisor moved or went on sabbatical or personality conflict. The respondents are also asked on whether they consider their supervisor to be their role model. Finally, in Section A, the respondents are asked on their satisfactory level in being supervised by the named $\mathrm{PhD}$ supervisor using a 5-point scale of 1 being 'very satisfied' to 5 being 'very dissatisfied'.

Section B seeks respondents' responses concerning the supervisory characteristics and characteristics of supervision. This section has two parts. The first part involves examining the impact of identified characteristics on the $\mathrm{PhD}$ supervisees' relationship with their supervisors. There are 13 questions in this part which includes availability to the supervisee, promptness in returning messages to supervisee, expectation made known to supervisee at beginning of program, schedule to accommodate demands in supervising supervisee, availability to discuss academic issues with supervisee, support given to supervisee's academic problems, belief in supervisee's ability, guidance in preparation of proposal, guidance in writing thesis, amount of constructive feedback provided to supervisee's research proposal, amount of constructive feedback provided to supervisee's thesis, and open to ideas on the direction of supervisee's research.

The second part of Section B seeks to examine the impact of the characteristics identified on supervisees' study and degree outcome. There are 13 questions in this part. All 13 questions are similar to the questions in the first part. However, the responses are on the impact of the characteristics of supervisory relationship towards the supervisees' study and degree outcome whereas in the first part of Section $\mathrm{C}$, the respondents are asked to response the eleven questions towards the supervisory relationship. The respondents are asked to response using a 5-point scale of 1 being 'very negative impact' to 5 being 'very positive impact'.

Section $\mathrm{C}$ seeks to examine the satisfaction and impact of identified characteristics of supervisory relationship with $\mathrm{PhD}$ supervisors towards their study and degree outcome. There are 11 questions in this part which include supervisee's accessibility, schedule in meeting demands of graduate school, ability to meet deadlines, enthusiasm in his/ her research, attitude towards their studies, competency in undertaking a research project, willingness to seek new information, willingness in sharing authorship on joint projects, motivation to complete their program on time and willingness to admit mistakes. The respondents are asked to complete this question on a 5-point scale of 1 being 'very dissatisfied' to 5 being 'very satisfied'. 


\subsection{Data Collection Procedure}

Data collection was conducted between the months of January to July 2010. Three hundred questionnaires were distributed to $\mathrm{PhD}$ supervisees and their respective supervisors. The data collection involved two stages. The first stage involved sending out questionnaire to the $\mathrm{PhD}$ supervisors. Supervisor of each supervisee was identified from the records obtained from the Human Resource and Development office. The questionnaires were sent out to the $\mathrm{PhD}$ supervisors personally by the researchers. A set of questionnaire was given to each respondent requesting them to complete within a month. The questionnaire was coded to ensure that the $\mathrm{PhD}$ supervisor's responses be matched his/ her $\mathrm{PhD}$ supervisee. For example: if a set of questionnaire is coded 1 for the $\mathrm{PhD}$ supervisor, then the other set for questionnaire is also coded 1 for the $\mathrm{PhD}$ supervisee being supervised by the $\mathrm{PhD}$ supervisor coded ' 1 '.

The second stage involved sending out questionnaire to the graduated and ongoing $\mathrm{PhD}$ supervisees. The simple random sampling from a list of $\mathrm{PhD}$ supervisees were selected to participate in this study. The questionnaires were sent out to the $\mathrm{PhD}$ supervisees via mail. A set of questionnaire was sent with a formal letter identifying the purpose of such study and requesting them to complete and return the questionnaire using the self-addressed envelope provided. Throughout the 6 months period of January to June 2010, $73 \mathrm{PhD}$ supervisors responded and $86 \mathrm{PhD}$ supervisees responded. A preliminary screening of the questionnaire received back has revealed that only 51 matching sample has responded to the questionnaire survey. As such, the questionnaire received from unmatched sample was excluded from the study.

\section{Results and Discussion}

\subsection{Demographic Profile}

Table 1 presents the demographic profile of the respondents which has been divided into supervisee or supervisor. The characteristics of the respondents were evaluated on the basis of the following criteria: gender, age, their position in the organisation. The results in panel A, Table 1 show that out of the 51 supervisee that has responded, 13 (25.5\%) were males and 38 $(74.5 \%)$ were females. This scenario has appeared to be consistent with the supervisor where females tended to dominate $(82.3 \%)$.

Panel B, Table 1 presents the results showing the age group of the respondents for both groups. The results show that a majority of the supervisee were from the age group of $31-49(80.4 \%)$. Only $3(5.8 \%)$ of the respondents were less than 30 years old. It is interesting to highlight that $7(13.8 \%)$ of the respondents from supervisee group were above 50 years old. In contrast, all (100\%) of the respondents from supervisor group were above 40 years old. 
Table 1. Descriptive Statistics of Demographic Profile

Panel A: Gender

\begin{tabular}{lcccc}
\hline & \multicolumn{2}{c}{ PhD Supervisee } & \multicolumn{2}{c}{ PhD Supervisor } \\
\cline { 2 - 5 } & $\mathrm{N}$ & $\%$ & $\mathrm{~N}$ & $\%$ \\
\hline Male & 13 & 25.5 & 9 & 17.6 \\
Female & 38 & 74.5 & 42 & 82.3 \\
\hline
\end{tabular}

Panel B: Age

\begin{tabular}{lcccc}
\hline & \multicolumn{2}{c}{ PhD Supervisee } & \multicolumn{2}{c}{ PhD Supervisor } \\
\cline { 2 - 5 } & $\mathrm{N}$ & $\%$ & $\mathrm{~N}$ & $\%$ \\
\hline Below 30 years & 3 & 5.8 & - & - \\
31-39 years & 21 & 41.2 & - & - \\
40-49 years & 20 & 39.2 & 12 & 23.5 \\
50 and above & 7 & 13.8 & 39 & 76.5 \\
\hline
\end{tabular}

Panel C: Present Position (PhD supervisor only)

\begin{tabular}{lcc}
\hline & $\mathrm{N}$ & $\%$ \\
\hline Senior Lecturer & 3 & 5.8 \\
Assistant/ Associate Professor & 33 & 64.7 \\
Professor & 15 & 29.4 \\
\hline
\end{tabular}

Panel D: Post Graduation Period (PhD supervisee only)

\begin{tabular}{lcc}
\hline & $\mathrm{N}$ & $\%$ \\
\hline In progress & 28 & 55 \\
Below 2.99 years & 8 & 15.7 \\
3 to 3.99 years & 6 & 11.8 \\
4 years and above & 4 & 7.8 \\
\hline
\end{tabular}

Panel E: Supervising Experience (PhD supervisor only)

\begin{tabular}{lcc}
\hline & $\mathrm{N}$ & $\%$ \\
\hline Below 5 years & 6 & 11.8 \\
6-10 years & 21 & 41.2 \\
$11-15$ years & 19 & 37.2 \\
Above 20 years & 5 & 9.8 \\
\hline
\end{tabular}

The questionnaires also required the respondents of $\mathrm{PhD}$ supervisors to indicate their present position in the university. The results are shown in panel C, Table 1 . The results show that 48 (94\%) of the supervisor group were at least Associate professors. Such results provide indication that one needs to have at least holding an Associate Professor position to become PhD supervisors. 


\section{Macrothink}

The results in panel $\mathrm{D}$, Table 1 show that in terms of years after completing $\mathrm{PhD}$, slightly more than half of the respondents were still in the process of completing their $\mathrm{PhD}$. The results show that 28 out of the 51 (55\%) respondents in the $\mathrm{PhD}$ supervisee group have yet to complete their research study. The remaining $45 \%$ of the respondents in the $\mathrm{PhD}$ supervisee groups have completed their research study with $7.8 \%$ graduated more than 4 years ago.

Panel E, Table 1 shows that almost half of the respondents in the $\mathrm{PhD}$ supervisor group have had a lot of supervising experience. At least $45(88 \%)$ had more than 6 years of supervising experience. $21(41.2 \%)$ had between 6-10 years of experience and $19(37.2 \%)$ had 11-15 years of supervising experience. The result has shown that only $6(11.8 \%)$ had less than six years of supervising experience.

\subsection{Supervisory Relationship}

Table 2 shows the descriptive statistics of supervisory relationship which has been divided into $\mathrm{PhD}$ supervisees or PhD supervisors. Panel A, Table 2 presents the choice in selecting their $\mathrm{PhD}$ supervisor or supervisee. The results reveal that majority of the respondents $(94 \%)$ in the $\mathrm{PhD}$ supervisee group agree that they have the choice to select their supervisor. Only 3 (6\%) of the respondents in the $\mathrm{PhD}$ supervisee group were not given the choice to choose their supervisor. In contrast, more than half majority of the respondents in the $\mathrm{PhD}$ supervisor group (59\%) responded that they have not given the choice to choose their supervisee. The results provide an earlier sign of possible conflicting needs of supervisory relationship.

Table 2. Supervisory Relationship

Panel A: Choice of Supervision

\begin{tabular}{lcccc}
\hline & \multicolumn{2}{c}{ PhD Supervisee } & \multicolumn{2}{c}{ PhD Supervisor } \\
\cline { 2 - 5 } & $\mathrm{N}$ & $\%$ & $\mathrm{~N}$ & $\%$ \\
\hline Yes & 48 & 94.1 & 21 & 41.2 \\
No & 3 & 5.9 & 30 & 58.8 \\
\hline
\end{tabular}

Panel B: Satisfaction in Supervision

\begin{tabular}{lcccc}
\hline & \multicolumn{2}{c}{ PhD Supervisee } & \multicolumn{2}{c}{ PhD Supervisor } \\
\cline { 2 - 5 } & $\mathrm{N}$ & $\%$ & $\mathrm{~N}$ & $\%$ \\
\hline Very satisfied & 20 & 39.2 & 3 & 5.8 \\
Satisfied & 24 & 47.0 & 42 & 82.3 \\
Neutral & 5 & 9.8 & 4 & 7.8 \\
Dissatisfied & 2 & 3.9 & 2 & 3.9 \\
Very Dissatisfied & 0 & 0 & 0 & 0 \\
\hline
\end{tabular}

Panel C: Supervisor as a Role Model

\begin{tabular}{llc}
\hline & $\mathrm{N}$ & $\%$ \\
\hline Yes & 19 & 37.2 \\
No & 32 & 62.8
\end{tabular}


Panel B, Table 2 presents the results showing whether the two groups were happy with their supervisory relationship. The results show an interesting finding where 44 out of $51(86.2 \%)$ of the respondents in the $\mathrm{PhD}$ supervisee group were satisfied with their relationship with their supervisor. Such results are not consistent to previous studies that show most $\mathrm{PhD}$ supervisees were not satisfied with their supervisory relationship (Young et al., 1987; Hockey, 1991; Acker et al., 1994). Similarly, 88.1\% of the respondents in the $\mathrm{PhD}$ supervisor groups were satisfied with their supervisory relationship. Specifically, there are $20(39 \%)$ respondents in the $\mathrm{PhD}$ supervisee group who were very satisfied with their supervisory relationship. In contrast, only $3(6 \%)$ of the $\mathrm{PhD}$ supervisors were very satisfied with the relationship.

The results in panel B, Table 2 show that only a small number of respondents in both groups who were not satisfied or neutral towards their supervisory relationship. There were 2 respondents from both groups agreed that they were not happy with the relationship. Only 7 (13.7\%) and $6(11.7 \%) \mathrm{PhD}$ supervisees and $\mathrm{PhD}$ supervisors respectively, agree that they are neutral or dissatisfied with the relationship, results which are consistent to Young et al. (1987), Hockey (1991) and Acker et al. (1994).

The respondents were also asked whether they consider their $\mathrm{PhD}$ supervisors to be a positive role model. The results in panel C, Table 2 show that only 19 (37\%) of the supervisee agree to the statement. The remaining $32(63 \%)$ of the respondents in the $\mathrm{PhD}$ supervisee group disagreed that their $\mathrm{PhD}$ supervisors have provided them a positive role model. The results provide an indication that the PhD supervisees did not look highly on their PhD supervisors.

\subsection{Supervisory Selection Criteria}

This section presents the response to the first research question (RQ1). RQ1 states that "What are the supervisory selection criteria of the PhD supervisors and supervisees?" Table 3 presents the results of the mean score for $\mathrm{PhD}$ supervisee group and $\mathrm{PhD}$ supervisor group. The results reveal that both groups have different opinion about the ranking of the factors. The $\mathrm{PhD}$ supervisee group agrees that having common research interest is a primary factor in choosing their supervisor (mean score=4.4510). In contrast, the $\mathrm{PhD}$ supervisor group perceived common research interest as the least important factor (mean score $=1.4510$ ).

In the eyes of the respondents of $\mathrm{PhD}$ supervisee group, the $\mathrm{PhD}$ supervisor's professional reputation is ranked second most important factor with a mean score of 4.3725 . Whereas in the eyes of the respondents of the $\mathrm{PhD}$ supervisor group, they perceived the $\mathrm{PhD}$ supervisees' past research and work experience as a major influence in choosing their supervisee (mean score $=3.9805$ ). Both groups however agreed that to have a healthy supervisory relationship, previous experience working with each other prior to $\mathrm{PhD}$ research study is not an important factors in deciding their supervisory relationship (mean score $=2.7059$, ranked fifth and mean score $=3.0196$, ranked fourth respectively). Such results support the earlier results shown in panel B, Table 2 . 
Table 3. Supervision Selection Criteria

\begin{tabular}{lrrrr}
\hline & \multicolumn{3}{c}{ PhD supervisee } & \multicolumn{2}{c}{ PhD Supervisor } \\
\cline { 2 - 5 } & Rank & Mean & Rank & Mean \\
\hline Common research interest & 1 & 4.4510 & 5 & 1.4510 \\
\hline $\begin{array}{l}\text { Supervisor's professional reputation/ } \\
\begin{array}{l}\text { Supervisee's past research and work } \\
\text { experience }\end{array}\end{array}$ & 2 & 4.3725 & 1 & 3.9804 \\
\hline $\begin{array}{l}\text { Supervisors'/supervisee's work habit } \\
\text { and personality }\end{array}$ & 3 & 4.3333 & 3 & 3.3333 \\
\hline Recommendation from colleague & 4 & 3.7843 & 2 & 3.6078 \\
\hline $\begin{array}{l}\text { Recruited by supervisor/ Research } \\
\text { member }\end{array}$ & 5 & 2.7059 & 4 & 3.0196 \\
\hline
\end{tabular}

\subsection{Satisfaction on Characteristics of Supervisory Relationship}

This section presents the response to the second research question (RQ2) developed in this study. RQ2 states that "Are the PhD supervisors and supervisees satisfied with their supervisory relationship?" Table 4 presents the results of the mean score for $\mathrm{PhD}$ supervisee group and $\mathrm{PhD}$ supervisor group. The results show the extent of agreement between the two groups on their level of satisfaction on their supervisory relationship. The results reveal that both groups have different opinion about the ranking of the factors. The $\mathrm{PhD}$ supervisor group perceived the highest for the factor "my availability to this study" with a mean score of 4.5882 , followed closely by the factor "I provide guidance on my supervisee's thesis" with a mean score of 4.4706 and the factor "My schedule could accommodate the demand of supervision" with a mean score of 4.4118 .

Although the satisfaction level of supervisory relationship between the $\mathrm{PhD}$ supervisee group and the $\mathrm{PhD}$ supervisor group is somewhat similar, the different mean score given by both group reflect that the level of satisfaction on supervisory relationship of the PhD supervisee group is lower compared to the $\mathrm{PhD}$ supervisor group.

The results also show that the PhD supervisee group has the least satisfaction level on the following variable "Supervisor provide constructive feedback on my proposal" with a mean score of 3.7255, indicating that they were not happy with their $\mathrm{PhD}$ supervisors' performance in giving constructive feedback on their proposal. In contrast, the PhD supervisors have somewhat more higher satisfaction level that they have provided a good performance in giving constructive comments on their supervisees' proposal (mean score $=4.3922$ ), a finding that supports the results in panel B, Table 2 . 
Table 4. Satisfaction level of characteristics on supervisory relationship

\begin{tabular}{|c|c|c|c|}
\hline & Position & Mean & $\begin{array}{r}\text { Std. } \\
\text { Deviation }\end{array}$ \\
\hline Supervisor is easily accessible & Supervisee & 4.0784 & 0.7705 \\
\hline My availability to this supervisee & Supervisor & 4.5882 & 0.6380 \\
\hline Supervisor return messages promptly & Supervisee & 4.1176 & 0.8160 \\
\hline $\begin{array}{l}\text { My promptness in returning messages to } \\
\text { supervisee }\end{array}$ & Supervisor & 3.8824 & 1.2107 \\
\hline Supervisor discussed expectation at first meeting & Supervisee & 4.0784 & 0.82081 \\
\hline The expectation I discussed at first meeting & Supervisor & 4.2941 & 0.70126 \\
\hline $\begin{array}{l}\text { Supervisor schedule accommodate the demand } \\
\text { of supervision }\end{array}$ & Supervisee & 3.8431 & 0.92461 \\
\hline $\begin{array}{l}\text { My schedule could accommodate the demand of } \\
\text { supervision }\end{array}$ & Supervisor & 4.4118 & 0.72599 \\
\hline Supervisor is available to discuss academic issue & Supervisee & 3.8431 & 1.0653 \\
\hline $\begin{array}{l}\text { I am available to discuss academic issue with } \\
\text { this supervisee }\end{array}$ & Supervisor & 4.2353 & 0.81457 \\
\hline $\begin{array}{l}\text { Supervisor is supportive of my academic } \\
\text { problem }\end{array}$ & Supervisee & 3.9608 & 0.91566 \\
\hline My support of this supervisee academic problem & Supervisor & 4.0196 & 0.61612 \\
\hline Supervisor believed in my ability & Supervisee & 3.9608 & 0.93725 \\
\hline My belief in this supervisee's ability & Supervisor & 4.3137 & 0.64777 \\
\hline Supervisor provide guidance on research topic & Supervisee & 4.0000 & 1.0392 \\
\hline I provide guidance on supervisee's research topic & Supervisor & 4.3922 & 0.60261 \\
\hline $\begin{array}{l}\text { Supervisor provide guidance on research } \\
\text { proposal }\end{array}$ & Supervisee & 3.9216 & 0.93473 \\
\hline $\begin{array}{l}\text { I provide guidance on supervisee's research } \\
\text { proposal }\end{array}$ & Supervisor & 4.3333 & 0.81650 \\
\hline Supervisor provide guidance on my thesis & Supervisee & 3.8235 & 1.0527 \\
\hline I provide guidance on supervisee's thesis & Supervisor & 4.4706 & 0.64352 \\
\hline $\begin{array}{l}\text { Supervisor provide constructive feedback on my } \\
\text { proposal }\end{array}$ & Supervisee & 3.7255 & 1.0407 \\
\hline $\begin{array}{l}\text { I provide constructive feedback on supervisee's } \\
\text { proposal }\end{array}$ & Supervisor & 4.3922 & 1.0968 \\
\hline $\begin{array}{l}\text { Supervisor provide constructive feedback on my } \\
\text { thesis }\end{array}$ & Supervisee & 3.8235 & 1.0335 \\
\hline $\begin{array}{l}\text { I provide constructive feedback on supervisee's } \\
\text { thesis }\end{array}$ & Supervisor & 4.0784 & 1.1285 \\
\hline $\begin{array}{l}\text { Supervisor is open to ideas about research } \\
\text { direction }\end{array}$ & Supervisee & 3.9020 & 1.0817 \\
\hline I am open to ideas about research direction & Supervisor & 4.2745 & 0.89618 \\
\hline
\end{tabular}




\subsection{Impact of Characteristics of Supervisory Relationship on Degree Outcome}

This section presents the response to the third research question (RQ3) developed in this study. RQ3 states that "What do the PhD supervisors and supervisees perceived the impact of supervisory characteristics on the degree outcome?". Table 5 presents the results of the mean score for the response of the impact of supervisory relationship characteristics on $\mathrm{PhD}$ supervisees' degree outcome. The results showing both $\mathrm{PhD}$ supervisor group and the $\mathrm{PhD}$ supervisee group agreement that there are few characteristics on the supervisory relationship that may impact the supervisees' degree outcome needs to be highlighted.

As shown in Table 5, in most instances, both groups have no significant difference opinion about the supervisory relationship characteristics. However, it is interesting to highlight that there is significant different in terms of $\mathrm{PhD}$ supervisor being accessible to the supervisee. The $\mathrm{PhD}$ supervisor group believed that they find difficulty in accessing their supervisees (mean score $=3.6275$ ) whereas the $\mathrm{PhD}$ supervisee group felt that their supervisors could be accessible easily (mean score $=4.1569)$.

In addition, the $\mathrm{PhD}$ supervisee group felt that their $\mathrm{PhD}$ supervisors' schedule is less in accommodating the demand of supervision (mean score=4.0588). In contrast, the $\mathrm{PhD}$ supervisor group believed that their work schedule could still accommodate the demand of supervision (mean score=4.4706). Such results provide an indication that there is an expectation gap between the $\mathrm{PhD}$ supervisor group and $\mathrm{PhD}$ supervisee group, results that are consistent to previous studies in the supervisory relationship literature.

The $\mathrm{PhD}$ supervisee group, on the other hand perceived the highest for the factor "Supervisor return messages promptly" with a mean score of 4.1176 , followed by the factor "Supervisor is easily accessible" (mean score=4.0784) and "Supervisor discussed expectation at first meeting" (mean score=4.0784). Although the satisfaction level of supervisory relationship between the $\mathrm{PhD}$ supervisee group and the $\mathrm{PhD}$ supervisor group is somewhat similar, the different mean score given by both group reflect that the level of satisfaction on supervisory relationship of the $\mathrm{PhD}$ supervisee group is lower compared to the $\mathrm{PhD}$ supervisor group.

The results also show that the $\mathrm{PhD}$ supervisee group has the least satisfaction level on the following variable "Supervisor provide constructive feedback on my proposal" with a mean score of 3.7255, indicating that they were not happy with their $\mathrm{PhD}$ supervisors' performance in giving constructive feedback on their proposal.

The $\mathrm{PhD}$ supervisee group, on the other hand perceived the highest for the factor "Supervisor return messages promptly" with a mean score of 4.1176 , followed by the factor "Supervisor is easily accessible" (mean score=4.0784) and "Supervisor discussed expectation at first meeting" (mean score=4.0784). 
Table 5. The impact of identified characteristics on the degree outcome

\begin{tabular}{|c|c|c|c|}
\hline & Position & Mean & $\begin{array}{r}\text { Std. } \\
\text { Deviation }\end{array}$ \\
\hline Supervisor is easily accessible & Supervisee & 4.1569 & 0.73137 \\
\hline My availability to supervisee & Supervisor & 3.6275 & 0.82367 \\
\hline Supervisor return message promptly & Supervisee & 4.1176 & 0.73884 \\
\hline $\begin{array}{l}\text { My promptness in returning message to this } \\
\text { supervisee }\end{array}$ & Supervisor & 3.9804 & 0.96933 \\
\hline $\begin{array}{l}\text { Supervisor discuss expectation at the beginning } \\
\text { of program }\end{array}$ & Supervisee & 4.0784 & 0.71675 \\
\hline $\begin{array}{l}\text { The expectation I discussed at the beginning of } \\
\text { program }\end{array}$ & Supervisor & 4.0392 & 0.99922 \\
\hline $\begin{array}{l}\text { Supervisor schedule accommodate the demand of } \\
\text { supervision }\end{array}$ & Supervisee & 4.0588 & 0.90359 \\
\hline $\begin{array}{l}\text { My schedule could accommodate the demand of } \\
\text { supervision }\end{array}$ & Supervisor & 4.4706 & 0.92418 \\
\hline Supervisor is available to discuss academic issue & Supervisee & 4.0980 & 0.94350 \\
\hline $\begin{array}{l}\text { I am available to discuss academic issue with this } \\
\text { supervisee }\end{array}$ & Supervisor & 4.1569 & 1.15538 \\
\hline Supervisor is supportive of my academic problem & Supervisee & 4.1176 & 0.97256 \\
\hline My support of supervisee's academic problem & Supervisor & 3.9020 & 1.06311 \\
\hline Supervisor believed in my ability & Supervisee & 4.0980 & 1.15334 \\
\hline My belief in supervisee's ability & Supervisor & 4.1176 & 0.90878 \\
\hline Supervisor provides guidance on research topic & Supervisee & 4.3725 & 0.69169 \\
\hline I provide guidance on supervisee's research topic & Supervisor & 4.1373 & 0.91694 \\
\hline $\begin{array}{l}\text { Supervisor provides guidance on research } \\
\text { proposal }\end{array}$ & Supervisee & 4.7451 & 5.56001 \\
\hline $\begin{array}{l}\text { I provide guidance on supervisee's research } \\
\text { proposal }\end{array}$ & Supervisor & 3.8431 & 1.23891 \\
\hline Supervisor provides guidance on my thesis & Supervisee & 3.9804 & 0.88295 \\
\hline I provide guidance on supervisee's thesis & Supervisor & 3.8824 & 1.21074 \\
\hline
\end{tabular}

\subsection{Impact of Characteristics of Supervisory Relationship on Supervisee's Satisfaction and} Degree Outcome

This section presents the response to the last research question (RQ4) developed in this study. RQ4 states that "What is the perceived impact of supervisory characteristics on supervisee's satisfaction and degree outcome of the PhD supervisors and supervisees. Table 6 presents the results of the mean score for $\mathrm{PhD}$ supervisee group and $\mathrm{PhD}$ supervisor group. The results show the impact of supervisory relationship characteristics on $\mathrm{PhD}$ supervisees' satisfaction and degree outcome. The results reveal that both groups have different opinion about the impact of supervisory relationship characteristics. 
Specifically, the $\mathrm{PhD}$ supervisee group perceived the highest for the factor "My enthusiasm about my research" with a mean score of 4.7059 , followed closely by the factor "My willingness to admit mistake" with a mean score of 4.6479. However, the $\mathrm{PhD}$ supervisor group perceived variables of "Supervisee's attitude about study" with a mean score of 4.3529 and "Supervisee's willingness to seek new information" with a mean score 4.2353 as the most important supervisory relationship characteristics.

Table 6. The impact of identified characteristics on $\mathrm{PhD}$ supervisees' satisfaction and degree outcome

\begin{tabular}{|c|c|c|c|}
\hline & Position & Mean & $\begin{array}{r}\text { Std. } \\
\text { Deviation }\end{array}$ \\
\hline Supervisor is easily accessible & Supervisee & 4.6078 & 0.60261 \\
\hline My availability to supervisee & Supervisor & 3.8431 & 0.88029 \\
\hline $\begin{array}{l}\text { My personal schedule could accommodate the demand } \\
\text { of graduate school }\end{array}$ & Supervisee & 4.4314 & 0.85452 \\
\hline $\begin{array}{l}\text { Supervisee's schedule be accommodate the demand of } \\
\mathrm{PhD} \text { graduate school }\end{array}$ & Supervisor & 4.2157 & 1.00625 \\
\hline My ability to meet deadlines & Supervisee & 4.5294 & 0.75771 \\
\hline Supervisee's ability to meet deadlines & Supervisor & 4.1176 & 1.08898 \\
\hline The respect for my supervisor privacy/ personal issue & Supervisee & 4.4902 & 0.85726 \\
\hline The respect for my supervisee's privacy/ personal issue & Supervisor & 3.8431 & 1.02708 \\
\hline My enthusiasm about my research & Supervisee & 4.7059 & 0.60973 \\
\hline Supervisee's enthusiasm about research & Supervisor & 4.0392 & 0.63121 \\
\hline Attitude about my study & Supervisee & 4.6275 & 0.79902 \\
\hline Supervisee's attitude about study & Supervisor & 4.3529 & 0.91266 \\
\hline My competence to undertake a research project & Supervisee & 4.4902 & 0.83361 \\
\hline $\begin{array}{l}\text { Supervisee's competence to undertake a research } \\
\text { project }\end{array}$ & Supervisor & 4.0784 & 1.12859 \\
\hline My willingness to seek new information & Supervisee & 4.4510 & 0.83220 \\
\hline Supervisee's willingness to seek new information & Supervisor & 4.2353 & 1.06936 \\
\hline My willingness to share authorship on joint projects & Supervisee & 4.5098 & 0.80926 \\
\hline $\begin{array}{l}\text { Supervisee's willingness to share authorship on joint } \\
\text { projects }\end{array}$ & Supervisor & 4.1765 & 0.93179 \\
\hline My motivation to complete study on time & Supervisee & 4.5686 & 0.78115 \\
\hline Supervisee's motivation to complete study on time & Supervisor & 4.0000 & 1.09545 \\
\hline My willingness to admit mistake & Supervisee & 4.6471 & 0.77003 \\
\hline Supervisee's willingness to admit mistake & Supervisor & 3.9020 & 0.70014 \\
\hline
\end{tabular}


Such results provide indication that there is an expectation gap between the $\mathrm{PhD}$ supervisor group and $\mathrm{PhD}$ supervisee group. The results show that both groups have different ideas on the importance of the supervisory relationship characteristics in determining supervisees' satisfaction and degree outcome. On the other hand, the PhD supervisors felt that their availability to their supervisees and the respect for supervisees' privacy/ personal issue are not important supervisory relationship characteristics in determining supervisees' satisfaction and degree outcome.

\section{Summary and Conclusion}

This study contributes to the literature in several areas. It provides a contribution to the understanding of the supervisory relationship in the $\mathrm{PhD}$ context. Understanding supervisory relationship could assist current and future $\mathrm{PhD}$ supervisors and supervisees to determine what are the characteristics of supervisory relationship that could leads to problems which eventuate to expectation gap. By tackling these problems, would hopefully reduce the expectation gap between the $\mathrm{PhD}$ supervisors and their supervisees.

This study examines the supervisory selection criteria of the $\mathrm{PhD}$ supervisees and $\mathrm{PhD}$ supervisors in selecting their supervisors and supervisees. The results show that $\mathrm{PhD}$ supervisee group tend to agree that having common research interest is a primary factor in choosing their supervisors. However, the $\mathrm{PhD}$ supervisor group perceived common research interest as the least important factor in selecting a supervisee. The $\mathrm{PhD}$ supervisees also perceived professional reputation of the supervisors as an important factor whereas the $\mathrm{PhD}$ supervisors perceived the $\mathrm{PhD}$ supervisees' past research and work experience as a major influence in choosing their supervisee.

The results in this study also show that $\mathrm{PhD}$ supervisors and $\mathrm{PhD}$ supervisees have different satisfaction level on the supervisory relationship characteristics. $\mathrm{PhD}$ supervisors were satisfied with their availability to their supervisees, provided guidance on their supervisee's thesis and being their schedule that could accommodate the supervision demand. $\mathrm{PhD}$ supervisees, on the other hand were more satisfied with their supervisors returning messages promptly, their supervisor being easily accessible and their supervisor discussed expectation at first meeting.

A key finding in this study is that the selection criteria and satisfaction of supervisory relationship characteristics vary between the $\mathrm{PhD}$ supervisors and supervisees. Therefore, it is recommended that $\mathrm{PhD}$ supervisees need to be aware of the supervisory selection criteria of their potential supervisors in order to be accepted by the later party. $\mathrm{PhD}$ supervisees also need to be aware of the supervisory relationship characteristics expected by their $\mathrm{PhD}$ supervisors need order to complete their study successfully.

This study is not without limitations. First, in this study the sample of the supervisee groups was taken from academics in the accounting discipline of a public university in Malaysia. Hence, it is not certain if the findings of this study can be generalized to other academic discipline or even accounting discipline from other universities. 
Second, the findings in this study are based on the questionnaire developed from Drysdale (2001) with some modifications. There are other types of questionnaire instrument that could be adapted in the study. Using other questionnaire instrument may be able to provide different conclusion.

\section{Acknowledgment}

The research is financed by Research Management Institute, Universiti Teknologi MARA.

\section{References}

Acker, S., Hill, T., \& Black, E. (1994) Thesis supervision in the social science: managed or negotiated? Higher Education, 28, 483-498.

Armstrong, D. (2004). Emotions in organisations. In C. Huffington, D.

Bernard, J. M., \& Goodyear, R. K. (1992). Fundamentals of clinical supervision. Boston: Allyn \& Bacon.

Connell, R. W. (1985). How to supervise a PhD. Vestes, 28(2), 38-42.

Cornwall, M. G., Schmithals, F., \& Jaques, D. (1977). What is project orientation?: An overview. Proceedings of the Seminar on Project Orientation in Higher Education (pp. 1-16). University of Bremen, March 1976, University of London, Institute of Education.

Delamont, S., Atkinson, P., \& Parry, O. (1997). Critical mass and doctoral research: Reflections on the Harris Report. Studies in Higher Education, 22(3), 319-31. http://dx.doi.org/10.1080/03075079712331380926

Dinham, S., \& Scott, C. (1999). The doctorate: Talking about the degree. University of Western Sydney: Nepean.

Drysdale, M. T. (2001). The quality and nature of supervisory relationship in graduate education: Student and supervisor perceptions. PhD thesis, The University of Calgary.

Dye, H. A. (1987). ACES attitudes: Supervisor competencies and a national certification program. ERIC/CAPS Resources in Education. Document No. ED 283098.

Dye, A. (1994). The supervisory relationship. ERIC Digest, 11.

Eggleston, J., \& Delamont, S. (1983). Supervision of students for research degrees. Birmingham, AL: BERA.

Freeman, S. C. (1992). C. H. Patterson on client-centered supervision: An interview. Counselor Education and Supervision, 31, 219-226. http://dx.doi.org/10.1002/j.1556-6978.1992.tb00164.x

Graham, A., \& Grant, B. (1997). Managing more postgraduate research students. Oxford, Oxford Centre for Staff Development.

Grant, B. (1999). Walking on a rackety bridge: mapping supervision. In Higher Education Research and Development Society of Australasia. 


\section{Macrothink

Gurr, G. M. (2001). Negotiating the "Rackety Bridge" - a Dynamic Model for Aligning Supervisory Style with Research Student Development. Higher Education Research \& Development, 20(1), 81. http://dx.doi.org/10.1080/07924360120043882

Hockey, J. (1991). The social science PhD-A literature review. Studies in Higher Education, 16(3), 319-332. http://dx.doi.org/10.1080/03075079112331382875

Johnston, T. (1999). Research supervision- setting the scene. In A. Holbrook \& S. Johnston (Eds), Supervision of Postgraduate Research in Education. Review of Australian Research in Education, 5, 17-31.

Kam, B. H. (1997). Style and quality in research supervision. Higher Education, 34(1), 81-103. http://dx.doi.org/10.1023/A:1002946922952

Laske, S., \& Zuber-Skerritt, O. (1996). Frameworks for postgraduate research and supervision. Lismore: Southern Cross University Press

McMorland, J., Carroll, S., \& Pringle, J. (2003). Enhancing the practice of PhD through first and second person action research/ peer partnership inquiry. Forum: Qualitative Social Research, 4(2), 37.

Moses, I. (1984). Supervision of higher degree students-problem areas and possible solutions. Higher Education Research and Development, 3(2), 153-165. http://dx.doi.org/10.1080/0729436840030204

Pearson, M., \& Brew, A. (2002). Research Training and Supervision Development. Studies in Higher Education, 27(2), 135-150. http://dx.doi.org/10.1080/03075070220119986c

Pearson, M., \& Kayrooz, C. (2004). Enabling critical reflection on research supervisory practice. International Journal for Academic Development, $9(1), 99$. http://dx.doi.org/10.1080/1360144042000296107

Ray, S. (2007). Selecting a doctoral dissertation supervisor: analytical hierarchy approach to the multiple criteria problem. International Journal of Doctoral Studies, 2, 23-32.

Ronnestad, M. H., \& Skovholt, T. M. (1993). Supervision of beginning and advanced graduate supervisees of counseling and psychotherapy. Journal of Counseling and Development, 71, 396-405. http://dx.doi.org/10.1002/j.1556-6676.1993.tb02655.x

Sharp, J. A., \& Howard, K. (1996). The Management of a Student Project (2nd ed.). Gower: Publishing, Aldershot, England.

Smeby, J. (2000). Same-gender relationships in graduate supervision. Higher Education, 40, 53-67. http://dx.doi.org/10.1023/A:1004040911469

Wisker, G., \& Sutcliffe, N. (1999). Good practice in postgraduate supervision. Birmingham: SEDA. 
Wright, J., \& Lodwick, R. (1989). The process of the PhD: A study of the first year of doctoral study. Research Papers in Education, 4, 22-56. http://dx.doi.org/10.1080/0267152890040103

Young, K., Forgarty, M. P., \& McRea, S. (1987). The management of doctoral studies in the social sciences. London, England: PSI.

\section{Copyright Disclaimer}

Copyright reserved by the authors.

This article is an open-access article distributed under the terms and conditions of the Creative Commons Attribution license (http://creativecommons.org/licenses/by/3.0/). 